\title{
Contributing Factors of Neurodegeneration in Alzheimer's Disease
}

\author{
Breeya Tailor • Alexander Pilozzi • Xudong Huang \\ Neurochemistry Laboratory, Department of Psychiatry, Massachusetts General Hospital and \\ Harvard Medical School, Charlestown, MA, USA
}

Author for correspondence: Xudong Huang, Neurochemistry Laboratory, Department of Psychiatry, Massachusetts General Hospital and Harvard Medical School, Charlestown, MA 02129, USA, Email: Huang.Xudong@mgh.harvard.edu

Doi: http://dx.doi.org/10.15586/alzheimersdisease.2019.ch5

\begin{abstract}
Alzheimer's Disease (AD) affects at least 5.7 million Americans, and it is the sixth leading cause of death in the United States. At the onset, patients experience minor memory problems. Next, impairments in speech and motor function manifest as a limitation to well-being and independence. Slowing this pandemic rise is critical, since $\mathrm{AD}$ also bears a huge socioeconomical burden. Unfortunately, there is limited prevention and no effective cure has been found, as all clinical trials for promising $\mathrm{AD}$ drugs have failed thus far. The pathological hallmarks of $\mathrm{AD}$ include amyloid- $\beta$ plaques (A $\beta$ ), neurofibrillary tangles (NFT), and neuroinflammation. Other factors include APOE4 and environmental stressors, such as metal dyshomeostasis, which contribute to AD pathogenesis. Herein, we review major contributing factors involved in AD pathophysiology. Deeper understanding of associated molecular mechanisms underlying AD pathogenesis is critical for developing novel AD theranostics.
\end{abstract}

Keywords: Amyloid- $\beta$; amyloid precursor protein; metals; $\beta$-site of APP cleaving enzyme 1 (BACE1 or $\beta$-secretase); neurotoxicity; NF-kB; presenilins

\footnotetext{
In: Alzheimer's Disease. Thomas Wisniewski (Editor), Codon Publications, Brisbane, Australia. ISBN: 978-0-646-80968-7; Doi: http://dx.doi.org/10.15586/alzheimersdisease.2019
}

Copyright: The Authors.

License: This open access article is licensed under Creative Commons Attribution 4.0 International (CC BY 4.0). https://creativecommons.org/licenses/by-nc/4.0/ 


\section{INTRODUCTION}

Alzheimer's disease (AD) is a progressive neurodegenerative disorder and is the most represented form of dementia. It is the 3rd most common disease affecting the population, inflicting at least 5.7 million Americans as the trend continues to rise at a pandemic rate. It is the leading cause of age-dependent disability on a global scale (1). AD reduces the quality of a patient's life, as irreversible cognitive decline becomes apparent due to pathological and morphological changes such as cortical atrophy, neuroinflammation, loss of synaptic connections, and cellular death (2) leaving the individual dependent on significant care, as their memories and motor function deteriorate.

Fortunately, technological advances have afforded researchers the ability to characterize neuronal loss in the hippocampus and cortices (3). Additional work has acknowledged perspectives on multifaceted complexities that have linked riskassociated genes and environmental factors to these differences (4). For example, increased exposure to air pollution, chemicals, and ionizing radiation is harmful $(5,6)$ and potentially contributes to dementia-related diseases. Unfortunately, AD has no efficacious treatments, and thus, the disease is a critical health concern and has incurred a colossal socioeconomic burden. Recently, the Alzheimer's Association reported the cost as $\$ 236$ billion and is projected to rise to $\$ 1.1$ trillion in 2050 (1). Therefore, identifying an accurate diagnosis and effective treatment is urgent.

The hallmarks of AD are evident, with neuroinflammation and aggregated $A \beta$ plaques followed by neurofibrillary tangles (NFT). In fact, recent studies observed plaque deposits within cognitively normal individuals up to 20 years before the onset of cognitive decline (7). Why A $\beta$ fibrils aggregate into plaques has yet to be elucidated; however, there is evidence that its exacerbated presence is toxic to neuronal cells. For example, A $\beta$ inhibits respiratory function, reduces ATP levels (8), and leads to mitochondrial dysfunction (9). In vitro studies of PC12 cells observed depolarization of the mitochondrial membrane potential and decreased activity of mitochondrial electron transport chain complexes. As $A \beta$ aggregates, it leads to signaling impairments causing the cells to undergo apoptosis. Anti-A $\beta$ drugs tested in human clinical trial have failed to produce promising results. As such, the credibility of the amyloid hypothesis has been questioned, and the true role of $A \beta$ is currently being investigated.

\section{AMYLOID PRECURSOR PROTEIN}

Amyloid plaques, or the insoluble $A \beta$ peptides, in the brain form through the cleavage of amyloid precursor protein (APP) by the b-site of APP cleaving enzyme 1 (BACEl or $\beta$-secretase) and $\gamma$-secretase $(10,11)$. APP is located on chromosome 21 , and it is a type I transmembrane protein involved in secretory and endocytic processes (12). It contains a metal-binding domain, heparin, collagen, laminin, and a protease inhibitor domain (13). Although the function of APP is unclear, there is evidence to suggest that the ectodomain of APP may be involved in cell adhesion, trophic support, cell growth, and differentiation of neuronal stem cells (14). Conversely, the intracellular domain may modulate mitochondrial function (15). 
APP can be processed through two pathways: the amyloidogenic pathway and the non-amyloidogenic pathway. In the amyloidogenic pathway, $\beta$-secretase cleaves APP at amino acid 671 releasing APP $\beta$ (sAPP $\beta$ ). Next, the CTF99 embedded in the plasma membrane is cleaved by $\gamma$-secretase, made up of 4 subunits $(16,17)$, including the catalytic domains Presenilin1 gene (PS1) and Presenilin2 (PS2) (18). BACE1 is a rate-limiting step for A production, and knockout studies result in complete inhibition of $A \beta$ generation (19). In the nonamyloidogenic pathway, APP is cleaved by $\alpha$-secretase at amino acid 687 , releasing soluble APP $\alpha$ (sAPP $\alpha$ ). The remaining protein, CTF83 is cleaved by $\gamma$-secretase releasing a soluble p3 fragment. $\alpha$-secretase belongs to a family of single-pass transmembrane and secretes zinc-containing endopeptidases that are dominant in neurons (20). Aggregated A $\beta$ function in normal physiology remains to be elucidated (19); however, $A \beta$ disrupts postsynaptic trafficking in glutamate receptors such as $\alpha$-amino-3-hydroxy-5-methyl-4-isoxazolepropionic acid (AMPA) receptors (21) and N-Methyl-D-Aspartate (NMDA) receptors (22). Their actions may be important for learning and memory, and synaptic plasticity (23-25). A $\beta$ has also been shown to modulate the inhibitory neurotransmitter gamma-aminobutyric acid (GABA) through interaction with KCC2 (26). A study by Senechal et al. investigated APP knockout mice and discovered dysregulated long-term potentiation (LTP) and learning deficits $(27,28)$. Moreover, theta-gamma oscillation phase-amplitude coupling was also diminished in regions of the parietal cortex and hippocampus compared to the wild type (27). As such, the function of APP is complex, and data so far have linked the role of the protein in neurite growth (29-31), axon guidance (32), and neuronal cell adhesion (33).

\section{$\beta$-SITE OF APP CLEAVING ENZYME 1}

$\beta$-site of APP cleaving enzyme 1 (BACE1) is a major drug target for therapy (34) because its expression correlates not only with the onset of AD but also with glucose intolerance. Importantly, this downstream effect is a risk factor for diabetes. Studies on mouse models which inhibit BACEl expression resulted in improvements in glucose homeostasis, lowered leptin levels, and decreased hypothalamic inflammation $(35,36)$. However, depletion of BACEl leads to other harmful effects as evidence suggests it important in regulating adult hippocampal neurons responsible for memory $(37,38)$ and other important neuronal processes. For example, mice models that possess faulty BACEl expression result in deficits in synaptic transmission and plasticity in the hippocampal region (39). Furthermore, the cell adhesion molecule Neuregulin-1 (Nrg1), which must be cleaved by BACEl, mediates radial migration of glutamatergic and GABAergic neurons. It is also responsible for myelination and synaptic plasticity (40) and is required for the formation of new synapses while strengthening existing ones. Interestingly, BACEl null mice result in a reduction of Nrgl cleavage, resulting in characteristics of schizophrenia (41). Similarly, Sez6 is a protein that is concentrated in areas associated with morphological plasticity. This includes areas within the hippocampus and cerebellum in postnatal brains. Sez6 is also cleaved by BACE1 and mediates dendritic arborization of cortical neurons (42) which is critical for neuronal transfer of information. Thus, defective BACEl leads 
to poor motor coordination, weak balance, and cognitive deficits. Lastly, BACE1 deficiency also affects Jagged-1 (Jagl) that regulates astrogenesis/neurogenesis through Notch signaling pathway $(43,44)$ and contributes to memory formation. Therefore, suppression of this enzyme is a double-edged sword and more research is needed to help in AD patients.

\section{GENETIC RISK FACTORS OF ALZHEIMER DISEASE PATHOLOGY}

There are two forms of AD: sporadic and familial. The majority of the cases (approximately 95\%) are classified as sporadic late-onset AD (LOAD), while about $5 \%$ are classified as familial early-onset 1 AD (EOAD) with an autosomal dominant inheritance pattern. Sporadic AD is influenced by complex genetic variants combined with environmental factors (45). However, there is little evidence to define how this occurs. Early onset is caused by rare mutations in three genes located on chromosome $21(46,47)$ and chromosome 14 (48). The summary of genetic mutations implicated in LOAD is shown in Table 1 and EOAD is given in Table 2 (45).

\begin{tabular}{|c|c|c|c|c|}
\hline TABLE 1 & \multicolumn{4}{|c|}{ A summary of genetic mutations implicated in LOAD } \\
\hline Gene & Protein & Chromosome & Risk change \% & $\begin{array}{l}\text { Proposed molecular } \\
\text { phenotype }\end{array}$ \\
\hline$A P O E$ & Apolipoprotein E & $19 q 13$ & 400-1500\% & $\begin{array}{l}\text { Clearance of } A \beta \\
\text { Lipid metabolism }\end{array}$ \\
\hline$A B C A 7$ & $\begin{array}{l}\text { ATP-binding cassette } \\
\text { subfamily A member } 7\end{array}$ & 19p13.3 & $\sim 20 \%$ & $\begin{array}{l}\text { Lipid metabolism } \\
\text { Cellular signaling }\end{array}$ \\
\hline BINI & Bridgin integrator 1 & $2 q 14$ & $\sim 15 \%$ & $\begin{array}{l}\text { Production of } A \beta \\
\text { Clearance of } A \beta \\
\text { Cellular signaling }\end{array}$ \\
\hline CR1 & $\begin{array}{l}\text { Complement component } \\
\text { (3b/4b) receptor } 1\end{array}$ & $1 \mathrm{q} 32$ & $\sim 15 \%$ & $\begin{array}{l}\text { Clearance of } A \beta \\
\text { Innate immunity }\end{array}$ \\
\hline PICALM & $\begin{array}{l}\text { Phosphadylinositol-binding } \\
\text { clathrin assembly } \\
\text { molecule }\end{array}$ & $11 q 14$ & $\sim 15 \%$ & $\begin{array}{l}\text { Production of } A \beta \\
\text { Clearance of } A \beta \\
\text { Cellular signaling }\end{array}$ \\
\hline CD2AP & CD2-associated protein & $6 \mathrm{p} 12.3$ & $\sim 10 \%$ & Cellular Signaling \\
\hline CD33 & CD33 (Siglec 3) & $19 q 13.3$ & $\sim 10 \%$ & $\begin{array}{l}\text { Innate immunity } \\
\text { Degradation of }\end{array}$ \\
\hline$C L U$ & Clusterin & $8 \mathrm{p} 21.1$ & $\sim 10 \%$ & $\begin{array}{l}\text { Clearance of } A \beta \\
\text { Innate immunity }\end{array}$ \\
\hline EPHA1 & EPH receptor Al & $7 \mathrm{q} 34$ & $\sim 10 \%$ & $\begin{array}{l}\text { Cellular signaling } \\
\text { Innate immunity }\end{array}$ \\
\hline ATXN1 & Ataxin 1 & $6 \mathrm{p} 22.3$ & NA & Production of $A \beta$ \\
\hline
\end{tabular}




\section{TABLE 2 A summary of genetic mutations implicated in EAOD}

\begin{tabular}{llcl} 
Gene & Protein & Chromosome & Molecular phenotype \\
\hline APP & Amyloid $\beta$ protein precursor & $21 \mathrm{q} 21$ & Increased $\mathrm{A} \beta_{42} / \mathrm{A} \beta_{40}$ ratio \\
& & & Increased $\mathrm{A} \beta$ production \\
& & & Increased $\mathrm{A} \beta$ aggregation \\
PSEN1 & Presenilin 1 & $14 \mathrm{q} 24$ & Increased $\mathrm{A} \beta_{42} / \mathrm{A} \beta_{40}$ ratio \\
PSEN2 & Presenilin 2 & $1 \mathrm{q} 31$ & Increased $\mathrm{A} \beta_{42} / \mathrm{A} \beta_{40}$ ratio
\end{tabular}

Mutations in APP, Presenilin1 (PS1), and Presenilin2 (PS2) genes have been integral in the development of $\mathrm{AD}$ as they cause a disruption in the ratio of $\mathrm{A} \beta 42$ production (49). In normal physiology, presenilins, needed for the production of $A \beta$ peptides via both $\beta$ - and $\gamma$-secretases-mediated cleavage $(50,51)$, are responsible for autosomal transmission and the promotion of amyloid plaque. PS1 regulates calcium homeostasis and mediates neurotransmission $(52,53)$. The largest amount of mutations occurs for PS1 at an estimate of 200 mutants, whereas APP and PS2 have 10-25 mutants on the AD and frontotemporal dementia mutation database.

Meta-analysis revealed at least 15 potential loci where variations may predispose one to developing $\mathrm{AD}$ (46). However, a particular gene appears to be the most burdensome, the ApoE gene. It has four different isoforms: ApoEel, ApoEe2, ApoEe3, and ApoEe4. Apolipoprotein E (ApoE) regulates synaptic function, promotes plasticity, increases the number of dendritic spines, and regulates protein trafficking across neurons (54). It is responsible for the regulation of triglyceride and cholesterol metabolism. Binding of lipidated ApoE facilitates $A \beta$ uptake in an isoformdependent manner, and inhibited clearance contributes to $A \beta$ accumulation. One variant of ApoE gene has been identified as the largest risk factor for late-onset $\mathrm{AD}$ through computational analysis (55-57). It is important to note that possessing ApoEe4 over the e3 (common) or e2 (other variant) alleles is not enough to cause $\mathrm{AD}$ but it acts as a determinant which increases overtime as the patients ages (45). Analyses reveal that a heterozygous pair increases AD by threefold, whereas a homozygous pair increases the risk by 15 -fold (58). It is thought to be the least effective in binding to, and facilitating the uptake of, $A \beta$. Additionally, its strong ties to neurovascular dysfunction further confirm its contribution in AD manifestation (56). The allele can be investigated for potential biomarkers and to unearth new targets for $\mathrm{AD}$ drug discovery due to significant clinical and neurobiological correlations. Among them, ApoE e4 allele and low CSF level of A $\beta 42$ have been reported (59). Patients with the e4 allele tend to present with early-onset memory impairment, decrease in global cognitive function, and weak episodic memory (60). Interestingly, the ApoE e2 variant seems to reduce the risk of dementia compared to the common e3 allele, despite its association with an increased amyloid burden (56). Overall, monitoring ApoE gene can play an important role in understanding the AD pathophysiology and be used as an assessment tool for at-risk patients.

Other genes that have a strong association with late-onset AD include SORL1, which mediates protein trafficking (61), and ACE, which regulates blood pressure (62). Furthermore, testing a single nucleotide for any association with disease 
pathology can be accomplished through GWAS technology. One avenue leads to the discovery of GRB2, which mediates tau phosphorylation and has a high affinity for APP and the presinilins $(63,64)$. Other findings identified ATXN1, which affects $A \beta$ levels by modulating $\beta$-secretase levels and cleavage of APP (65), and BIN1 (66), which is highly expressed in the central nervous system and plays a role in receptor-mediated endocytosis (67). Furthermore, ADAM10 mutations have impaired enzyme activity and lead to the onset of AD in the elderly (67). Lastly, CD33 has been an interesting discovery because it helps strengthen that A $\beta$ acts as an $\operatorname{AMP}(11,68-70)$.

\section{THE NEUROIMMUNE SYSTEM}

There are many challenges in understanding the complexity of inflammation in relation to $\mathrm{AD}$ in order to develop appropriate therapeutics. Clinical analysis of AD patients exhibited chronic neuroinflammation, insufficient energy metabolism, and redox stress in postmortem brains (71). These observations have been replicated in both animal and cell culture models. Increased inflammatory cascade by microglia has been observed in areas of $A \beta$ deposits and activation of NF-kB $(72,73)$.

Due to their high affinity for $A \beta$ deposits, understanding the role of microglia may help identify therapeutic targets. In brief, microglia are recognized as the brain macrophage and play an integral role in housekeeping. Upon signal detection, they act to remove debris, toxins, pathogens, and apoptotic neurons $(74,75)$ by releasing a cascade of inflammatory factors. As such, they release reactive oxygen species and Thl cytokines including interleukin 1-beta (IL-1 $\beta$ ), IL-6, tumor necrosis factor alpha (TNF- $\alpha$ ), and interferon-gamma (76) to ramp up the immune system. Furthermore, they are integral in upregulating MCHII complexes, leading to an inflammatory cascade in innate immune response in many disorders such as Parkinson's disease, HIV, and multiple sclerosis (77-80). In AD brain, microglia are constantly aggregated around $A \beta$ plaques (81) to form a barrier between healthy tissue and areas of injured or infected tissue. Since there is no evidence to suggest microglia can degrade $A \beta$, they undergo a state of compromised phagocytosis, in which the semi-degraded $A \beta$ are ultimately expelled from the microglial cell (82) causing a dysregulation of homeostasis. Extended exposure to $A \beta$ leads to disrupted calcium homeostasis within astrocytic cells, which also leads to degeneration of neurons (83).

NF- $k B$ regulates the expression of more than 400 genes (72) and can be induced by ROS, interleukinIL-1 $\beta$, TNF- $\alpha$, bacterial lipopolysaccharides (LPS), isoproterenol, and ionizing radiation $(73,84)$. Its activation is dependent on growth factors and the neurotransmitter, glutamate (85). Thus, NF-kB plays an important role in DNA transcription and cellular survival. In general, high levels of NF-kB expression are associated with normal aging and upregulate microglial activity (85-87). This overexpression increases the susceptibility for AD through upregulating BACE1 and APP genes (88).

Furthermore, rodent models have demonstrated the outcomes of unregulated NF- $\mathrm{KB}$, resulting in a destructive feedback loop $(89,90)$. For example, mice that overexpressed NF-kB had clinical signs of increased apoptosis in the hippocampal 
region through triggering TNF- $\alpha$ and iNOS when exposed to neurotoxins $(91,92)$. Moreover, drosophila studies that overexpressed NF-kB in the hypothalamus-like pars intercerebralis resulted in deficits in learning, inadequate memory consolidation, and increase in mortality rates compared to the controls (93). Upon clinical analysis, imaging studies resulted in severe neurodegeneration (94).

Studies regarding the relationship between $\mathrm{AD}$ and lifestyle choices concluded that an increased risk of $\mathrm{AD}$ was associated with diabetes, high blood pressure, and smoking (95-97). Type 2 diabetes mellitus (T2DM) increases a patient's risk of developing $\mathrm{AD}$ by over $50 \%$ (45), and it affects the increase of $\mathrm{A} \beta$ pathology by its ability to upregulate NF-kB and the expression of BACEl $(98,99)$. As researchers continue their efforts in drug therapeutic development, alternative approaches have been sought, including cognitive exercises that have improved the production of dopamine and vitamin $C(100,101)$. Rats that were subjected to proinflammatory diets, and adhered to aerobic exercise, resulted in attenuated NF-kB expression in the liver and muscles. Similarly, regular exercise resulted in an increase of endurance, cognition, and performance (102-104). Unfortunately, standard models are not adequate in analyzing the effect of nutrition on the onset of $\mathrm{AD}$, and no study to date can definitively state the relationship (101).

\section{BLOOD-BRAIN BARRIER}

The blood-brain barrier (BBB) plays a vital role in the longevity of an individual's health, and it is responsible for the clearance of $A \beta$; thus, any insult that compromises the integrity of BBB can cause neuronal cells damage (105-107). New studies have observed the progression of AD along with compromised BBB (108). This negative effect is alarming as any damage to the neurovascular unit (NVU) results in toxic substance leaking into the CNS circulating in the blood. In fact, the mechanism of transporting $\mathrm{A} \beta$ out of brain is impaired in $\mathrm{AD}$ patients, which contributes substantially to its accumulation (107). One example is the dysfunction of P-glycoprotein (Pgp) (109) resulting in increased deposits and age-associated cognitive impairments. Furthermore, mediating glucose transport for neuronal functionality is integral for astrocytes and neurons, and expression of GLUTs is downregulated in patients. This decreases brain energy supply as confirmed by brain imaging studies (110). Other risks associated with an impaired BBB lead to insufficient nutrient supply and toxin removal, and altered protein expression, all impacting and upregulating the role of neurodegeneration $(111,112)$. Although it is not elucidated how the mechanism works, therapeutic interventions in alleviating the disease progression are necessary. Recent findings conclude that $\mathrm{AD}$ risk factors can be modulated with lifestyle changes in regard to increase in educational levels, exercise, and healthy dietary choices (113-115).

\section{METALS}

Strong evidence suggests that biometals in the brains of $\mathrm{AD}$ patients are insufficiently maintained, thereby promoting cognitive loss. Due to their structure and function, the proteins that play a role in $\mathrm{AD}$ pathophysiology have capabilities 
of interacting with metals, especially zinc and copper. Other transitional metals include lead, aluminum, and iron, which may negatively impact human health if the homeostasis is not maintained $(116,117)$. Neuronal damage can occur due to dysregulation of integral metals needed to maintain brain function. The accumulation of $\mathrm{Cu}$ ions has been identified around plaques in postmortem $\mathrm{AD}$ brains (118), suggesting the impact of $\mathrm{Cu}$ on $\mathrm{AD}$ progression. As such, excessive dietary $\mathrm{Cu}$ on high-cholesterol diet in rabbits and AD mouse model induces hallmark pathologies. Research has found that chronic exposure to $\mathrm{Cu}$ contributes to an increased risk of $\mathrm{AD}$ by facilitating $\mathrm{A} \beta$ accumulation (118).

Additionally, zinc regulates many proteins such as SNAP25, PSD95, AMPA receptors, and NMDA receptors. ZnT3, a zinc transporter, allows for the release of zinc from neurons into synapses and is involved in cognition and memory. The disruption in mechanism results in cognitive decline (120). Likewise, AD mouse brains have irregular protein levels of CamKII, spinophilin, NMDA receptors, and $\operatorname{BDNF}(119,121)$. Interestingly, $A D$ transgenic mice studies indicated $A \beta$ amyloid aggregated in areas of high $\mathrm{Fe}, \mathrm{Cu}$, and $\mathrm{Zn}$ levels, indicating accumulation of metals within the brain promotes the aggregation of the A $\beta$ peptides $(122,123)$. Recent studies have found that APP can regulate iron levels in the brain by removing it from cells, similar to ceruloplasmin. In AD, this activity is decreased by $70 \%$ in cortical tissue $(122,123)$. Tau knockout mice lacked the ability to clear out iron and developed age-dependent neurodegeneration. Rescue studies provided clues that quinoline activity may be a possible therapeutic for AD (124).

PBT2, currently in clinical trials, is a disease modifying drug that does not act like a chelator but as an ionophore $(119,121)$. Administration of PBT2 for 12 weeks improved mild forms of $\mathrm{AD}$ cases through executive function and composite cognitive $z$-scores and reduced the levels of $A \beta$ in cerebrospinal fluid $(125,126)$. Other studies also showed increased neurite outgrowth in vitro and decreased tau phosphorylation $(121,127)$.

Iron is critical for maintaining neuronal tissue and is involved in the synthesis of myelin and neurotransmitters. Conversely, excessive accumulation can enhance $A \beta$ production and tau dysfunction leading to neuronal cell death. Parallel to how iron increases expression of ferritin and ferroportin, iron also increases the processing of $\operatorname{APP}(128,129)$. This causes formation of senile plaques and leads to oxidative stress, resulting in oligomerization and more A $\beta$ generation (130). Iron dysregulation increases NFT (131) creating an iron-rich population within oxidatively stressed environments (132). Quantitative mapping that displays an increase in iron loading shows a strong predictor for cognitive decline. The disruption of iron levels affects neuronal populations within the hippocampus through Fenton and Haber-Weiss reactions (133), producing oxidative lipids that further increase the neurotoxicity and AD pathogenesis (134). As stated, NFT is the integral for trafficking APP to neuronal membrane to facilitate iron efflux from neurons $(122,135)$, and thus, the loss of tau expression increases the risk for cognitive loss and cortical atrophy in mice (124).

The effects of aluminum on neurodegeneration have attracted attention since it can cause mitochondrial dysfunction and ATP depletion at the cellular level, and decline in memory and cognitive performance on a psychiatric level $(136,137)$. It can also cause apoptosis in neurons (138). Biopsy studies have confirmed elevated levels of aluminum in LOAD brains, possible source being drinking water (139). 


\section{CONCLUSION}

AD significantly reduces patients' quality of life. Therefore, there is an urgent need to develop early detection diagnostics and preventive measures to slow the progress of the onset until the discovery of a cure. Serial failures of clinical trials for AD experimental drugs have led us to reevaluate the pathology of this devastating disease and to embark on further understanding of the underlying AD pathophysiology and associated contributing factors. Agents against targets such as BACEl and APP amyloidosis have proved to be ineffective against AD progression so far. Therefore, further studies in AD pathogenic mechanisms and future utility of artificial intelligence (AI)-based drug discovery tools may aid in developing novel theranostic agents for $\mathrm{AD}(140,141)$.

Acknowledgments: This work was partially supported by a grant from $\mathrm{NIH}$ National Institute on Aging (R01AG056614 to XH).

Conflict of interest: The authors declare no potential conflicts of interest with respect to research, authorship, and/or publication of this chapter.

Copyright and Permission Statement: To the best of our knowledge, the materials included in this chapter do not violate copyright laws. All original sources have been appropriately acknowledged and/or referenced. Where relevant, appropriate permissions have been obtained from the original copyright holder(s).

\section{REFERENCES}

1. Alzheimer's Association. 2016 Alzheimer's disease facts and figures. Alzheimers Dement. 2016;12(4):459-509. http://dx.doi.org/10.1016/j.jalz.2016.03.001

2. Selkoe DJ. Alzheimer's disease is a synaptic failure. Science. 2002;298(5594):789-91. http://dx.doi. org/10.1016/j.jalz.2016.03.001

3. Hossini AM, Megges M, Prigione A, Lichtner B, Toliat MR, Wruck W, et al. Induced pluripotent stem cell-derived neuronal cells from a sporadic Alzheimer's disease donor as a model for investigating AD-associated gene regulatory networks. BMC Genomics. 2015;16:84. http://dx.doi.org/10.1186/ s12864-015-1262-5

4. Yuede CM, Timson BF, Hettinger JC, Yuede KM, Edwards HM, Lawson JE, et al. Interactions between stress and physical activity on Alzheimer's disease pathology. Neurobiol Stress. 2018;8:158-71. http:// dx.doi.org/10.1016/j.ynstr.2018.02.004

5. Calderon-Garciduenas L, Vojdani A, Blaurock-Busch E, Busch Y, Friedle A, Franco-Lira M, et al. Air pollution and children: Neural and tight junction antibodies and combustion metals, the role of barrier breakdown and brain immunity in neurodegeneration. J Alzheimers Dis. 2015;43(3):1039-58. http://dx.doi.org/10.3233/JAD-141365

6. Oudin A, Forsberg B, Adolfsson AN, Lind N, Modig L, Nordin M, et al. Traffic-related air pollution and dementia incidence in Northern Sweden: A longitudinal study. Environ Health Perspect. 2016;124(3):306-12. http://dx.doi.org/10.1289/ehp.1408322

7. Burns JM, Swerdlow RH. Backwaters and rapids on the amyloid river. Neurology. 2013;80(10):878-9. http://dx.doi.org/10.1212/WNL.0b013e3182840dl4

8. Rhein V, Baysang G, Rao S, Meier F, Bonert A, Muller-Spahn F, et al. Amyloid-beta leads to impaired cellular respiration, energy production and mitochondrial electron chain complex activities in 
human neuroblastoma cells. Cell Mol Neurobiol. 2009;29(6-7):1063-71. http://dx.doi.org/10.1007/ s10571-009-9398-y

9. Swerdlow RH. Mitochondria and cell bioenergetics: Increasingly recognized components and a possible etiologic cause of Alzheimer's disease. Antioxid Redox Signal. 2012;16(12):1434-55. http:// dx.doi.org/10.1089/ars.2011.4149

10. Zhang H, Ma Q, Zhang YW, Xu H. Proteolytic processing of Alzheimer's beta-amyloid precursor protein. J Neurochem. 2012;120(Suppl 1):9-21. http://dx.doi.org/10.1111/j.1471-4159.2011.07519.x

11. Bertram L, Tanzi RE. The genetic epidemiology of neurodegenerative disease. J Clin Invest. 2005;115(6):1449-57. http://dx.doi.org/10.1172/JCI24761

12. Matsui T, Ingelsson M, Fukumoto H, Ramasamy K, Kowa H, Frosch MP, et al. Expression of APP pathway mRNAs and proteins in Alzheimer's disease. Brain Res. 2007;1161:116-23. http:// dx.doi.org/10.1016/j.brainres.2007.05.050

13. Dawkins E, Small DH. Insights into the physiological function of the beta-amyloid precursor protein: Beyond Alzheimer's disease. J Neurochem. 2014;129(5):756-69. http://dx.doi.org/10.1111/ jnc. 12675

14. Young-Pearse TL, Chen AC, Chang R, Marquez C, Selkoe DJ. Secreted APP regulates the function of full-length APP in neurite outgrowth through interaction with integrin betal. Neural Dev. 2008;3:15. http://dx.doi.org/10.1186/1749-8104-3-15

15. Muller T, Meyer HE, Egensperger R, Marcus K. The amyloid precursor protein intracellular domain (AICD) as modulator of gene expression, apoptosis, and cytoskeletal dynamics-relevance for Alzheimer's disease. Prog Neurobiol. 2008;85(4):393-406. http://dx.doi.org/10.1016/j.pneurobio.2008.05.002

16. Bolduc DM, Montagna DR, Gu Y, Selkoe DJ, Wolfe MS. Nicastrin functions to sterically hinder gamma-secretase-substrate interactions driven by substrate transmembrane domain. Proc Natl Acad Sci U S A. 2016;113(5):E509-18. http://dx.doi.org/10.1073/pnas.1512952113

17. Holmes O, Paturi S, Selkoe DJ, Wolfe MS. Pen-2 is essential for gamma-secretase complex stability and trafficking but partially dispensable for endoproteolysis. Biochemistry. 2014;53(27):4393-406. http://dx.doi.org/10.1021/bi500489j

18. Zhang YW, Thompson R, Zhang H, Xu H. APP processing in Alzheimer's disease. Mol Brain. 2011;4:3. http://dx.doi.org/10.1186/1756-6606-4-3

19. Kumar DK, Choi SH, Washicosky KJ, Eimer WA, Tucker S, Ghofrani J, et al. Amyloid-beta peptide protects against microbial infection in mouse and worm models of Alzheimer's disease. Sci Transl Med. 2016;8(340):340ra72. http://dx.doi.org/10.1126/scitranslmed.aaf1059

20. Kuhn PH, Wang H, Dislich B, Colombo A, Zeitschel U, Ellwart JW, et al. ADAMlO is the physiologically relevant, constitutive alpha-secretase of the amyloid precursor protein in primary neurons. EMBO J. 2010;29(17):3020-32. http://dx.doi.org/10.1038/emboj.2010.167

21. Gu Z, Liu W, Yan Z. \{beta\}-Amyloid impairs AMPA receptor trafficking and function by reducing Ca2+/ calmodulin-dependent protein kinase II synaptic distribution. J Biol Chem. 2009;284(16):10639-49. http://dx.doi.org/10.1074/jbc.M806508200

22. Snyder EM, Nong Y, Almeida CG, Paul S, Moran T, Choi EY, et al. Regulation of NMDA receptor trafficking by amyloid-beta. Nat Neurosci. 2005;8(8):1051-8. http://dx.doi.org/10.1038/nn1503

23. Hick M, Herrmann U, Weyer SW, Mallm JP, Tschape JA, Borgers M, et al. Acute function of secreted amyloid precursor protein fragment APPs alpha in synaptic plasticity. Acta Neuropathol. 2015;129(1):21-37. http://dx.doi.org/10.1007/s00401-014-1368-x

24. Taylor CJ, Ireland DR, Ballagh I, Bourne K, Marechal NM, Turner PR, et al. Endogenous secreted amyloid precursor protein-alpha regulates hippocampal NMDA receptor function, long-term potentiation and spatial memory. Neurobiol Dis. 2008;31(2):250-60. http://dx.doi.org/10.1016/j.nbd.2008.04.011

25. Preat T, Goguel V. Role of drosophila amyloid precursor protein in memory formation. Front Mol Neurosci. 2016;9:142. http://dx.doi.org/10.3389/fnmol.2016.00142

26. Doshina A, Gourgue F, Onizuka M, Opsomer R, Wang P, Ando K, et al. Cortical cells reveal APP as a new player in the regulation of GABAergic neurotransmission. Sci Rep. 2017;7(1):370. http://dx.doi. org/10.1038/s41598-017-00325-2

27. Zhang X, Zhong W, Brankack J, Weyer SW, Muller UC, Tort AB, et al. Impaired theta-gamma coupling in APP-deficient mice. Sci Rep. 2016;6:21948. http://dx.doi.org/10.1038/srep21948 
28. Senechal Y, Kelly PH, Dev KK. Amyloid precursor protein knockout mice show age-dependent deficits in passive avoidance learning. Behav Brain Res. 2008;186(1):126-32. http://dx.doi. org/10.1016/j.bbr.2007.08.003

29. Hoareau C, Borrell V, Soriano E, Krebs MO, Prochiantz A, Allinquant B. Amyloid precursor protein cytoplasmic domain antagonizes reelin neurite outgrowth inhibition of hippocampal neurons. Neurobiol Aging. 2008;29(4):542-53. http://dx.doi.org/10.1016/j.neurobiolaging.2006.11.012

30. Rama N, Goldschneider D, Corset V, Lambert J, Pays L, Mehlen P. Amyloid precursor protein regulates netrin-1-mediated commissural axon outgrowth. J Biol Chem. 2012;287(35):30014-23. http://dx.doi.org/10.1074/jbc.M111.324780

31. Chen K, Lu H, Gao T, Xue X, Wang C, Miao F. Synergic interaction between amyloid precursor protein and neural cell adhesion molecule promotes neurite outgrowth. Oncotarget. 2016;7(12):14199-206. http://dx.doi.org/10.18632/oncotarget.7348

32. Wang B, Li H, Mutlu SA, Bowser DA, Moore MJ, Wang MC, et al. The amyloid precursor protein is a conserved receptor for slit to mediate axon guidance. eNeuro. 2017;4(3):ENEURO.0185-17.2017. http://dx.doi.org/10.1523/ENEURO.0185-17.2017

33. Sosa LJ, Caceres A, Dupraz S, Oksdath M, Quiroga S, Lorenzo A. The physiological role of the amyloid precursor protein as an adhesion molecule in the developing nervous system. J Neurochem. 2017;143(1):11-29. http://dx.doi.org/10.1111/jnc.14122

34. Evin G, Hince C. BACEl as a therapeutic target in Alzheimer's disease: Rationale and current status. Drugs Aging. 2013;30(10):755-64. http://dx.doi.org/10.1007/s40266-013-0099-3

35. Meakin PJ, Harper AJ, Hamilton DL, Gallagher J, McNeilly AD, Burgess LA, et al. Reduction in BACE1 decreases body weight, protects against diet-induced obesity and enhances insulin sensitivity in mice. Biochem J. 2012;441(1):285-96. http://dx.doi.org/10.1042/BJ20110512

36. Zhao WQ, Townsend M. Insulin resistance and amyloidogenesis as common molecular foundation for type 2 diabetes and Alzheimer's disease. Biochim Biophys Acta. 2009;1792(5):482-96. http://dx.doi. org/10.1016/j.bbadis.2008.10.014

37. Chatila ZK, Kim E, Berle C, Bylykbashi E, Rompala A, Oram MK, et al. BACEl regulates proliferation and neuronal differentiation of newborn cells in the adult hippocampus in mice. eNeuro. 2018;5(4):pii: ENEURO.0067-18.2018. http://dx.doi.org/10.1523/ENEURO.0067-18.2018

38. Vassar R. BACEl inhibitor drugs in clinical trials for Alzheimer's disease. Alzheimers Res Ther. 2014;6(9):89. http://dx.doi.org/10.1186/s13195-014-0089-7

39. Dominguez D, Tournoy J, Hartmann D, Huth T, Cryns K, Deforce S, et al. Phenotypic and biochemical analyses of BACE1- and BACE2-deficient mice. J Biol Chem. 2005;280(35):30797-806. http://dx.doi. org/10.1074/jbc.M505249200

40. Mei L, Nave KA. Neuregulin-ERBB signaling in the nervous system and neuropsychiatric diseases. Neuron. 2014;83(1):27-49. http://dx.doi.org/10.1016/j.neuron.2014.06.007

41. Stefansson H, Sigurdsson E, Steinthorsdottir V, Bjornsdottir S, Sigmundsson T, Ghosh S, et al. Neuregulin 1 and susceptibility to schizophrenia. Am J Hum Genet. 2002;71(4):877-92. http:// dx.doi.org/10.1086/342734

42. Gunnersen JM, Kim MH, Fuller SJ, De Silva M, Britto JM, Hammond VE, et al. Sez-6 proteins affect dendritic arborization patterns and excitability of cortical pyramidal neurons. Neuron. 2007;56(4):621-39. http://dx.doi.org/10.1016/j.neuron.2007.09.018

43. Hu X, He W, Luo X, Tsubota KE, Yan R. BACEl regulates hippocampal astrogenesis via the Jagged 1-Notch pathway. Cell Rep. 2013;4(1):40-9. http://dx.doi.org/10.1016/j.celrep.2013.06.005

44. Gaiano N, Fishell G. The role of notch in promoting glial and neural stem cell fates. Annu Rev Neurosci. 2002;25:471-90. http://dx.doi.org/10.1146/annurev.neuro.25.030702.130823

45. Tanzi RE. The genetics of Alzheimer disease. Cold Spring Harb Perspect Med. 2012;2(10):pii: a006296. http://dx.doi.org/10.1101/cshperspect.a006296

46. Hardy J, Selkoe DJ. The amyloid hypothesis of Alzheimer's disease: Progress and problems on the road to therapeutics. Science. 2002;297(5580):353-6. http://dx.doi.org/10.1126/science.1072994

47. Tanzi RE, Gusella JF, Watkins PC, Bruns GA, St George-Hyslop P, Van Keuren ML, et al. Amyloid beta protein gene: cDNA, mRNA distribution, and genetic linkage near the Alzheimer locus. Science. 1987;235(4791):880-4. http://dx.doi.org/10.1126/science.2949367 
48. Sherrington R, Rogaev EI, Liang Y, Rogaeva EA, Levesque G, Ikeda M, et al. Cloning of a gene bearing missense mutations in early-onset familial Alzheimer's disease. Nature. 1995;375(6534):754-60. http://dx.doi.org/10.1038/375754a0

49. Tanzi RE, Bertram L. Twenty years of the Alzheimer's disease amyloid hypothesis: A genetic perspective. Cell. 2005;120(4):545-55. http://dx.doi.org/10.1016/j.cell.2005.02.008

50. De Strooper B, Saftig P, Craessaerts K, Vanderstichele H, Guhde G, Annaert W, et al. Deficiency of presenilin-1 inhibits the normal cleavage of amyloid precursor protein. Nature. 1998;391(6665):387-90. http://dx.doi.org/10.1038/34910

51. Kounnas MZ, Danks AM, Cheng S, Tyree C, Ackerman E, Zhang X, et al. Modulation of gamma-secretase reduces beta-amyloid deposition in a transgenic mouse model of Alzheimer's disease. Neuron. 2010;67(5):769-80. http://dx.doi.org/10.1016/j.neuron.2010.08.018

52. Bezprozvanny I, Hiesinger PR. The synaptic maintenance problem: Membrane recycling, $\mathrm{Ca} 2+$ homeostasis and late onset degeneration. Mol Neurodegener. 2013;8:23. http://dx.doi. org/10.1186/1750-1326-8-23

53. Mattson MP. ER calcium and Alzheimer's disease: In a state of flux. Sci Signal. 2010;3(114):pe10. http://dx.doi.org/10.1126/scisignal.3114pe10

54. Dumanis SB, Cha HJ, Song JM, Trotter JH, Spitzer M, Lee JY, et al. ApoE receptor 2 regulates synapse and dendritic spine formation. PLoS One. 2011;6(2):e17203. http://dx.doi.org/10.1371/journal.pone.0017203

55. Liu CC, Liu CC, Kanekiyo T, Xu H, Bu G. Apolipoprotein E and Alzheimer disease: Risk, mechanisms and therapy. Nat Rev Neurol. 2013;9(2):106-18. http://dx.doi.org/10.1038/nrneurol.2012.263

56. Holtzman DM, Herz J, Bu G. Apolipoprotein E and apolipoprotein E receptors: Normal biology and roles in Alzheimer disease. Cold Spring Harb Perspect Med. 2012;2(3):a006312. http://dx.doi. org/10.1101/cshperspect.a006312

57. Lambert JC, Ibrahim-Verbaas CA, Harold D, Naj AC, Sims R, Bellenguez C, et al. Meta-analysis of 74,046 individuals identifies 11 new susceptibility loci for Alzheimer's disease. Nat Genet. 2013;45(12):1452-8. http://dx.doi.org/10.1038/ng.2802

58. McGuinness B, Carson R, Barrett SL, Craig D, Passmore AP. Apolipoprotein epsilon 4 and neuropsychological performance in Alzheimer's disease and vascular dementia. Neurosci Lett. 2010;483(1):62-6. http://dx.doi.org/10.1016/j.neulet.2010.07.063

59. Sun X, Nicholas J, Walker A, Wagner MT, Bachman D. APOE genotype in the diagnosis of Alzheimer's disease in patients with cognitive impairment. Am J Alzheimers Dis Other Demen. 2012;27(5):315-20. http://dx.doi.org/10.1177/1533317512452037

60. Liu F, Pardo LM, Schuur M, Sanchez-Juan P, Isaacs A, Sleegers K, et al. The apolipoprotein E gene and its age-specific effects on cognitive function. Neurobiol Aging. 2010;31(10):1831-3. http://dx.doi. org/10.1016/j.neurobiolaging.2008.09.015

61. Rogaeva E, Meng Y, Lee JH, Gu Y, Kawarai T, Zou F, et al. The neuronal sortilin-related receptor SORLl is genetically associated with Alzheimer disease. Nat Genet. 2007;39(2):168-77. http:// dx.doi.org/10.1038/ng1943

62. Kehoe PG, Russ C, Mcllory S, Williams H, Holmans P, Holmes C, et al. Variation in DCP1, encoding ACE, is associated with susceptibility to Alzheimer disease. Nat Genet. 1999;21(1):71-2. http:// dx.doi.org/10.1038/5009

63. Reiman EM, Webster JA, Myers AJ, Hardy J, Dunckley T, Zismann VL, et al. GAB2 alleles modify Alzheimer's risk in APOE epsilon4 carriers. Neuron. 2007;54(5):713-20. http://dx.doi.org/10.1016/j. neuron.2007.05.022

64. Nizzari M, Venezia V, Repetto E, Caorsi V, Magrassi R, Gagliani MC, et al. Amyloid precursor protein and Presenilinl interact with the adaptor GRB2 and modulate ERK 1,2 signaling. J Biol Chem. 2007;282(18):13833-44. http://dx.doi.org/10.1074/jbc.M610146200

65. Zhang C, Browne A, Child D, Divito JR, Stevenson JA, Tanzi RE. Loss of function of ATXN1 increases amyloid beta-protein levels by potentiating beta-secretase processing of beta-amyloid precursor protein. J Biol Chem. 2010;285(12):8515-26. http://dx.doi.org/10.1074/jbc.M109.079079

66. Deming Y, Li Z, Kapoor M, Harari O, Del-Aguila JL, Black K, et al. Genome-wide association study identifies four novel loci associated with Alzheimer's endophenotypes and disease modifiers. Acta Neuropathol. 2017;133(5):839-56. http://dx.doi.org/10.1007/s00401-017-1685-y 
67. Pant S, Sharma M, Patel K, Caplan S, Carr CM, Grant BD. AMPH-1/Amphiphysin/Binl functions with RME-1/Ehdl in endocytic recycling. Nat Cell Biol. 2009;11(12):1399-410. http://dx.doi.org/ $10.1038 / \mathrm{ncb} 1986$

68. Soscia SJ, Kirby JE, Washicosky KJ, Tucker SM, Ingelsson M, Hyman B, et al. The Alzheimer's disease-associated amyloid beta-protein is an antimicrobial peptide. PLoS One. 2010;5(3):e9505. http:// dx.doi.org/10.1371/journal.pone.0009505

69. Hollingworth P, Harold D, Sims R, Gerrish A, Lambert JC, Carrasquillo MM, et al. Common variants at ABCA7, MS4A6A/MS4A4E, EPHA1, CD33 and CD2AP are associated with Alzheimer's disease. Nat Genet. 2011;43(5):429-35. http://dx.doi.org/10.1038/ng.803

70. Naj AC, Jun G, Beecham GW, Wang LS, Vardarajan BN, Buros J, et al. Common variants at MS4A4/ MS4A6E, CD2AP, CD33 and EPHAl are associated with late-onset Alzheimer's disease. Nat Genet. 2011;43(5):436-41. http://dx.doi.org/10.1038/ng.801

71. Vaz FNC, Fermino BL, Haskel MVL, Wouk J, de Freitas GBL, Fabbri R, et al. The relationship between copper, iron, and selenium levels and Alzheimer disease. Biol Trace Elem Res. 2018;181(2):185-91. http://dx.doi.org/10.1007/s12011-017-1042-y

72. Chow SK, Yu D, Macdonald CL, Buibas M, Silva GA. Amyloid beta-peptide directly induces spontaneous calcium transients, delayed intercellular calcium waves and gliosis in rat cortical astrocytes. ASN Neuro. 2010;2(1):e00026. http://dx.doi.org/10.1042/AN20090035

73. Karunaweera N, Raju R, Gyengesi E, Munch G. Plant polyphenols as inhibitors of NF-kappaB induced cytokine production-a potential anti-inflammatory treatment for Alzheimer's disease? Front Mol Neurosci. 2015;8:24. http://dx.doi.org/10.3389/fnmol.2015.00024

74. Bessis A, Bechade C, Bernard D, Roumier A. Microglial control of neuronal death and synaptic properties. Glia. 2007;55(3):233-8. http://dx.doi.org/10.1002/glia.20459

75. Caldero J, Brunet N, Ciutat D, Hereu M, Esquerda JE. Development of microglia in the chick embryo spinal cord: Implications in the regulation of motoneuronal survival and death. J Neurosci Res. 2009;87(11):2447-66. http://dx.doi.org/10.1002/jnr.22084

76. Lue LF, Rydel R, Brigham EF, Yang LB, Hampel H, Murphy GM, Jr., et al. Inflammatory repertoire of Alzheimer's disease and nondemented elderly microglia in vitro. Glia. 2001;35(1):72-9. http://dx.doi. org/10.1002/glia.1072

77. Garden GA. Microglia in human immunodeficiency virus-associated neurodegeneration. Glia. 2002;40(2):240-51. http://dx.doi.org/10.1002/glia.10155

78. Muzio L, Martino G, Furlan R. Multifaceted aspects of inflammation in multiple sclerosis: The role of microglia. J Neuroimmunol. 2007;191(1-2):39-44. http://dx.doi.org/10.1016/j.jneuroim.2007.09.016

79. Cameron B, Landreth GE. Inflammation, microglia, and Alzheimer's disease. Neurobiol Dis. 2010;37(3):503-9. http://dx.doi.org/10.1016/j.nbd.2009.10.006

80. McGeer PL, Itagaki S, McGeer EG. Expression of the histocompatibility glycoprotein HLA-DR in neurological disease. Acta Neuropathol. 1988;76(6):550-7. http://dx.doi.org/10.1007/BF00689592

81. Walker DG, Lue LF. Investigations with cultured human microglia on pathogenic mechanisms of Alzheimer's disease and other neurodegenerative diseases. J Neurosci Res. 2005;81(3):412-25. http:// dx.doi.org/10.1002/jnr.20484

82. Majumdar A, Chung H, Dolios G, Wang R, Asamoah N, Lobel P, et al. Degradation of fibrillar forms of Alzheimer's amyloid beta-peptide by macrophages. Neurobiol Aging. 2008;29(5):707-15. http:// dx.doi.org/10.1016/j.neurobiolaging.2006.12.001

83. Kounatidis I, Ligoxygakis P. Drosophila as a model system to unravel the layers of innate immunity to infection. Open Biol. 2012;2(5):120075. http://dx.doi.org/10.1098/rsob.120075

84. Wang L, Kounatidis I, Ligoxygakis P. Drosophila as a model to study the role of blood cells in inflammation, innate immunity and cancer. Front Cell Infect Microbiol. 2014;3:113. http://dx.doi. org/10.3389/fcimb.2013.00113

85. Meffert MK, Chang JM, Wiltgen BJ, Fanselow MS, Baltimore D. NF-kappa B functions in synaptic signaling and behavior. Nat Neurosci. 2003;6(10):1072-8. http://dx.doi.org/10.1038/nn1110

86. Kounatidis I, Chtarbanova S, Cao Y, Hayne M, Jayanth D, Ganetzky B, et al. NF-kappaB immunity in the brain determines fly lifespan in healthy aging and age-related neurodegeneration. Cell Rep. 2017;19(4):836-48. http://dx.doi.org/10.1016/j.celrep.2017.04.007 
87. Sadagurski M, Cady G, Miller RA. Anti-aging drugs reduce hypothalamic inflammation in a sex-specific manner. Aging Cell. 2017;16(4):652-60. http://dx.doi.org/10.1111/acel.12590

88. Chen CH, Zhou W, Liu S, Deng Y, Cai F, Tone M, et al. Increased NF-kappaB signalling up-regulates BACEl expression and its therapeutic potential in Alzheimer's disease. Int J Neuropsychopharmacol. 2012;15(1):77-90. http://dx.doi.org/10.1017/S1461145711000149

89. Baker RG, Hayden MS, Ghosh S. NF-kappaB, inflammation, and metabolic disease. Cell Metab. 2011;13(1):11-22. http://dx.doi.org/10.1016/j.cmet.2010.12.008

90. Purkayastha S, Zhang G, Cai D. Uncoupling the mechanisms of obesity and hypertension by targeting hypothalamic IKK-beta and NF-kappaB. Nat Med. 2011;17(7):883-7. http://dx.doi.org/10.1038/ nm. 2372

91. Niu YL, Zhang WJ, Wu P, Liu B, Sun GT, Yu DM, et al. Expression of the apoptosis-related proteins caspase-3 and NF-kappaB in the hippocampus of Tg2576 mice. Neurosci Bull. 2010;26(1):37-46. http://dx.doi.org/10.1007/s12264-010-6122-3

92. Rehman SU, Shah SA, Ali T, Chung JI, Kim MO. Anthocyanins reversed D-galactose-induced oxidative stress and neuroinflammation mediated cognitive impairment in adult rats. Mol Neurobiol. 2017;54(1):255-71. http://dx.doi.org/10.1007/s12035-015-9604-5

93. Zhang Y, Liu G, Yan J, Zhang Y, Li B, Cai D. Metabolic learning and memory formation by the brain influence systemic metabolic homeostasis. Nat Commun. 2015;6:6704. http://dx.doi.org/10.1038/ ncomms 7704

94. Li X, Song D, Leng SX. Link between type 2 diabetes and Alzheimer's disease: From epidemiology to mechanism and treatment. Clin Interv Aging. 2015;10:549-60. http://dx.doi.org/10.2147/CIA. S74042

95. Durazzo TC, Mattsson N, Weiner MW, Alzheimer's disease neuroimaging I. Smoking and increased Alzheimer's disease risk: A review of potential mechanisms. Alzheimers Dement. 2014;10(3 Suppl):S122-45. http://dx.doi.org/10.1016/j.jalz.2014.04.009

96. Quach A, Levine ME, Tanaka T, Lu AT, Chen BH, Ferrucci L, et al. Epigenetic clock analysis of diet, exercise, education, and lifestyle factors. Aging (Albany NY). 2017;9(2):419-46. http://dx.doi. org/10.18632/aging.101168

97. Bangen KJ, Gu Y, Gross AL, Schneider BC, Skinner JC, Benitez A, et al. Relationship between type 2 diabetes mellitus and cognitive change in a multiethnic elderly cohort. J Am Geriatr Soc. 2015;63(6):1075-83. http://dx.doi.org/10.1111/jgs.13441

98. Jonsson T, Atwal JK, Steinberg S, Snaedal J, Jonsson PV, Bjornsson S, et al. A mutation in APP protects against Alzheimer's disease and age-related cognitive decline. Nature. 2012;488(7409):96-9. http:// dx.doi.org/10.1038/nature11283

99. Vassar R, Kuhn PH, Haass C, Kennedy ME, Rajendran L, Wong PC, et al. Function, therapeutic potential and cell biology of BACE proteases: Current status and future prospects. J Neurochem. 2014;130(1):4-28. http://dx.doi.org/10.1111/jnc.12715

100. Yang J, Zhang X, Zhu Y, Lenczowski E, Tian Y, Yang J, et al. The double-edged role of copper in the fate of amyloid beta in the presence of anti-oxidants. Chem Sci. 2017;8(9):6155-64. http://dx.doi. org/10.1039/C7SC01787A

101. Gustafson DR, Clare Morris M, Scarmeas N, Shah RC, Sijben J, Yaffe K, et al. New perspectives on Alzheimer's disease and nutrition. J Alzheimers Dis. 2015;46(4):1111-27. http://dx.doi.org/10.3233/ JAD-150084

102. Botezelli JD, Coope A, Ghezzi AC, Cambri LT, Moura LP, Scariot PP, et al. Strength training prevents hyperinsulinemia, insulin resistance, and inflammation independent of weight loss in fructose-fed animals. Sci Rep. 2016;6:31106. http://dx.doi.org/10.3233/JAD-150084

103. Minegishi Y, Haramizu S, Misawa K, Shimotoyodome A, Hase T, Murase T. Deletion of nuclear factor-kappaB p50 upregulates fatty acid utilization and contributes to an anti-obesity and highendurance phenotype in mice. Am J Physiol Endocrinol Metab. 2015;309(6):E523-33. http://dx.doi. org/10.1152/ajpendo.00071.2015

104. Ropelle ER, Flores MB, Cintra DE, Rocha GZ, Pauli JR, Morari J, et al. IL-6 and IL-10 anti-inflammatory activity links exercise to hypothalamic insulin and leptin sensitivity through IKKbeta and ER stress inhibition. PLoS Biol. 2010;8(8):pii: el000465. http://dx.doi.org/10.1371/journal.pbio.1000465 
105. van de Haar HJ, Burgmans S, Hofman PA, Verhey FR, Jansen JF, Backes WH. Blood-brain barrier impairment in dementia: Current and future in vivo assessments. Neurosci Biobehav Rev. 2015;49:71-81. http://dx.doi.org/10.1016/j.neubiorev.2014.11.022

106. Bell RD, Zlokovic BV. Neurovascular mechanisms and blood-brain barrier disorder in Alzheimer's disease. Acta Neuropathol. 2009;118(1):103-13. http://dx.doi.org/10.1007/s00401-009-0522-3

107. Sagare AP, Bell RD, Zlokovic BV. Neurovascular dysfunction and faulty amyloid beta-peptide clearance in Alzheimer disease. Cold Spring Harb Perspect Med. 2012;2(10):pii: a011452. http://dx.doi. org/10.1101/cshperspect.a011452

108. Zenaro E, Piacentino G, Constantin G. The blood-brain barrier in Alzheimer's disease. Neurobiol Dis. 2017;107:41-56. http://dx.doi.org/10.1016/j.nbd.2016.07.007

109. van Assema DM, Lubberink M, Bauer M, van der Flier WM, Schuit RC, Windhorst AD, et al. Bloodbrain barrier P-glycoprotein function in Alzheimer's disease. Brain. 2012;135(Pt 1):181-9. http:// dx.doi.org/10.1093/brain/awr298

110. Chen Z, Zhong C. Decoding Alzheimer's disease from perturbed cerebral glucose metabolism: Implications for diagnostic and therapeutic strategies. Prog Neurobiol. 2013;108:21-43. http:// dx.doi.org/10.1016/j.pneurobio.2013.06.004

111. Goncalves A, Ambrosio AF, Fernandes R. Regulation of claudins in blood-tissue barriers under physiological and pathological states. Tissue Barriers. 2013;1(3):e24782. http://dx.doi.org/10.4161/tisb.24782

112. Carmeliet P, De Strooper B. Alzheimer's disease: A breach in the blood-brain barrier. Nature. 2012;485(7399):451-2. http://dx.doi.org/10.1038/48545la

113. McCartney DL, Stevenson AJ, Walker RM, Gibson J, Morris SW, Campbell A, et al. Investigating the relationship between DNA methylation age acceleration and risk factors for Alzheimer's disease. Alzheimers Dement (Amst). 2018;10:429-37. http://dx.doi.org/10.1016/j.dadm.2018.05.006

114. Livingston G, Frankish H. A global perspective on dementia care: A Lancet Commission. Lancet. 2015;386(9997):933-4. http://dx.doi.org/10.1016/S0140-6736(15)00078-1

115. Horvath S, Ritz BR. Increased epigenetic age and granulocyte counts in the blood of Parkinson's disease patients. Aging (Albany NY). 2015;7(12):1130-42. http://dx.doi.org/10.18632/aging.100859

116. Ayton S, Lei P, Bush AI. Metallostasis in Alzheimer's disease. Free Radic Biol Med. 2013;62:76-89. http://dx.doi.org/10.1016/j.freeradbiomed.2012.10.558

117. Bush AI. The metal theory of Alzheimer's disease. J Alzheimers Dis. 2013;33(Suppl 1):S277-81.

118. James SA, Churches QI, de Jonge MD, Birchall IE, Streltsov V, McColl G, et al. Iron, copper, and zinc concentration in abeta plaques in the APP/PS1 mouse model of Alzheimer's disease correlates with metal levels in the surrounding neuropil. ACS Chem Neurosci. 2017;8(3):629-37. http://dx.doi. org/10.1021/acschemneuro.6b00362

119. Adlard PA, Bica L, White AR, Nurjono M, Filiz G, Crouch PJ, et al. Metal ionophore treatment restores dendritic spine density and synaptic protein levels in a mouse model of Alzheimer's disease. PLoS One. 2011;6(3):e17669. http://dx.doi.org/10.1371/journal.pone.0017669

120. Miller Y, Ma B, Nussinov R. Zinc ions promote Alzheimer Abeta aggregation via population shift of polymorphic states. Proc Natl Acad Sci U S A. 2010;107(21):9490-5. http://dx.doi.org/10.1073/pnas.0913114107

121. Adlard PA, Cherny RA, Finkelstein DI, Gautier E, Robb E, Cortes M, et al. Rapid restoration of cognition in Alzheimer's transgenic mice with 8-hydroxy quinoline analogs is associated with decreased interstitial Abeta. Neuron. 2008;59(1):43-55. http://dx.doi.org/10.1016/j.neuron.2008.06.018

122. Duce JA, Tsatsanis A, Cater MA, James SA, Robb E, Wikhe K, et al. Iron-export ferroxidase activity of beta-amyloid precursor protein is inhibited by zinc in Alzheimer's disease. Cell. 2010;142(6):857-67. http://dx.doi.org/10.1016/j.cell.2010.08.014

123. Smith MA, Harris PL, Sayre LM, Perry G. Iron accumulation in Alzheimer disease is a source of redoxgenerated free radicals. Proc Natl Acad Sci U S A. 1997;94(18):9866-8. http://dx.doi.org/10.1073/ pnas.94.18.9866

124. Lei P, Ayton S, Finkelstein DI, Spoerri L, Ciccotosto GD, Wright DK, et al. Tau deficiency induces parkinsonism with dementia by impairing APP-mediated iron export. Nat Med. 2012;18(2):291-5. http://dx.doi.org/10.1038/nm.2613

125. Lannfelt L, Blennow K, Zetterberg H, Batsman S, Ames D, Harrison J, et al. Safety, efficacy, and biomarker findings of PBT2 in targeting Abeta as a modifying therapy for Alzheimer's disease: A phase IIa, 
double-blind, randomised, placebo-controlled trial. Lancet Neurol. 2008;7(9):779-86. http://dx.doi. org/10.1016/S1474-4422(08)70167-4

126. Faux NG, Ritchie CW, Gunn A, Rembach A, Tsatsanis A, Bedo J, et al. PBT2 rapidly improves cognition in Alzheimer's disease: Additional phase II analyses. J Alzheimers Dis. 2010;20(2):509-16. http:// dx. doi.org/10.3233/JAD-2010-1390

127. Crouch PJ, Savva MS, Hung LW, Donnelly PS, Mot AI, Parker SJ, et al. The Alzheimer's therapeutic PBT2 promotes amyloid-beta degradation and GSK3 phosphorylation via a metal chaperone activity. J Neurochem. 2011;119(1):220-30. http://dx.doi.org/10.1111/j.1471-4159.2011.07402.x

128. Rogers JT, Randall JD, Cahill CM, Eder PS, Huang X, Gunshin H, et al. An iron-responsive element type II in the 5'-untranslated region of the Alzheimer's amyloid precursor protein transcript. J Biol Chem. 2002;277(47):45518-28. http://dx.doi.org/10.1074/jbc.M207435200

129. Cho HH, Cahill CM, Vanderburg CR, Scherzer CR, Wang B, Huang X, et al. Selective translational control of the Alzheimer amyloid precursor protein transcript by iron regulatory protein-1. J Biol Chem. 2010;285(41):31217-32. http://dx.doi.org/10.1074/jbc.M110.149161

130. Zhang L, Zhao B, Yew DT, Kusiak JW, Roth GS. Processing of Alzheimer's amyloid precursor protein during H2O2-induced apoptosis in human neuronal cells. Biochem Biophys Res Commun. 1997;235(3):845-8. http://dx.doi.org/10.1006/bbrc.1997.6698

131. Ledesma MD, Avila J, Correas I. Isolation of a phosphorylated soluble tau fraction from Alzheimer's disease brain. Neurobiol Aging. 1995;16(4):515-22.

132. Jin Jung K, Hyun Kim D, Kyeong Lee E, Woo Song C, Pal Yu B, Young Chung H. Oxidative stress induces inactivation of protein phosphatase $2 \mathrm{~A}$, promoting proinflammatory NF-kappaB in aged rat kidney. Free Radic Biol Med. 2013;61:206-17. http://dx.doi.org/10.1016/0197-4580(95)00075-P

133. Ayton S, Fazlollahi A, Bourgeat P, Raniga P, Ng A, Lim YY, et al. Cerebral quantitative susceptibility mapping predicts amyloid-beta-related cognitive decline. Brain. 2017;140(8):2112-19. http://dx.doi. org/10.1093/brain/awx137

134. Gamblin TC, King ME, Kuret J, Berry RW, Binder LI. Oxidative regulation of fatty acid-induced tau polymerization. Biochemistry. 2000;39(46):14203-10. http://dx.doi.org/10.1021/bi0018761

135. McCarthy RC, Park YH, Kosman DJ. sAPP modulates iron efflux from brain microvascular endothelial cells by stabilizing the ferrous iron exporter ferroportin. EMBO Rep. 2014;15(7):809-15. http:// dx.doi.org/10.15252/embr.201338064

136. Giorgianni CM, D’Arrigo G, Brecciaroli R, Abbate A, Spatari G, Tringali MA, et al. Neurocognitive effects in welders exposed to aluminium. Toxicol Ind Health. 2014;30(4):347-56. http://dx.doi. org/10.1177/0748233712456062

137. Inan-Eroglu E, Ayaz A. Is aluminum exposure a risk factor for neurological disorders? J Res Med Sci. 2018;23:51. http://dx.doi.org/10.4103/jrms.JRMS_921_17

138. Bharathi, Vasudevaraju P, Govindaraju M, Palanisamy AP, Sambamurti K, Rao KS. Molecular toxicity of aluminium in relation to neurodegeneration. Indian J Med Res. 2008;128(4):545-56.

139. McLachlan DR, Bergeron C, Smith JE, Boomer D, Rifat SL. Risk for neuropathologically confirmed Alzheimer's disease and residual aluminum in municipal drinking water employing weighted residential histories. Neurology. 1996;46(2):401-5. http://dx.doi.org/10.1212/WNL.46.2.401

140. Carpenter KA, Cohen DS, Jarrell JT, Huang X. Deep learning and virtual drug screening. Future Med Chem. 2018. http://dx.doi.org/10.4155/fmc-2018-0314

141. Carpenter KA, Huang X. Machine learning-based virtual screening and its applications to Alzheimer's drug discovery: A review. Curr Pharm Des. 2018;24(28):3347-58. http://dx.doi.org/10.2174/138161 2824666180607124038 